\title{
PATOLOGI SOSIAL DAN DAMPAKNYA TERHADAP REMAJA
}

\author{
Ulfah Fajarini \\ UIN Syarif Hidayatullah Jakarta, Indonesia \\ E-mail: ulfah.fajarini@uinjkt.ac.id
}

\begin{abstract}
The development of the city of Jakarta, has an impact on the surrounding area, especially in the Ciputat region, accompanied by very rapid population growth. This article discusses social pathology. Qualitative research methods in the form of interviews and observations. There are social pathologies (social ills), such as stress, increased crime, unemployment, juvenile delinquency, and prostitution. The negative impact also occurs in adolescents in the Ciputat-Tangerang sub-district, which is located in South Jakarta.
\end{abstract}

Keywords: Social pathology; impact on adolescents

Abstrak. Perkembangan kota Jakarta, berdampak pada wilayah sekitarnya, khususnya di wilayah Ciputat, diiringi dengan pertumbuhan penduduk yang sangat pesat. Artikel ini membahas mengenai patologi sosial. Metode penelitian kualitatif berupa wawancara dan pengamatan. Adanya patologi sosial (penyakit sosial), seperti stress, meningkatnya kriminalitas, pengangguran, kenakalan remaja serta prostitusi.. Dampak negatif tersebut juga terjadi pada remaja di daerah kecamatan Ciputat- Tangerang, yang berada di Selatan Jakarta.

Kata Kunci: Patologi sosial; dampak terhadap remaja

Permalink/DOI: https://doi.org/10.15408/harkat.v15i1.13444 


\section{Pendahuluan}

Guru besar ilmu kesehatan jiwa Universitas Indonesia (UI). Prof. Dr. Dadang Hawari menilai "penyakit sosial” yang mendera bangsa Indonesia sudah semakin kronis. Jika hal itu terus dibiarkan terjadi, sangat berbahaya bagi kelangsungan NKRI (Negara Kesatuan Republik Indonesia) (Suara Pembaruan, 14 Mei 2001).

Penilaian di atas sebenarnya merupakan generalisasi dari realitas yang memang terjadi di beberapa daerah di Indonesia - baik di tingkat provinsi, kabupaten mapun di tingkat kecamatan, atau bahkan juga yang terjadi di wilayah yang lebih kecil seperti kelurahan atau desa misalnya.

Secara kultural, realitas di atas karena disebabkan oleh menurunnya kehidupan moral masyarakat akibat munculnya sikap mendewakan materi dan uang di nilai jauh lebih berperan dari pada aturan dan hukum, sehingga masyarakat hilang kepekaan untuk mengatur hidup berdasarkan iman moral dan ideologi bangsa. Sedangkan secara struktural, penyakit sosial yang mengidap masyarakat itu bisa juga karena disebabkan oleh pesatnya urbanisasi dan perkembangan kota yang terkait didalamnya perkembangan sosial, politik, ekonomi, serta budaya yang menyebabkan masyarakat tidak mampu beradaptasi terhadap perkembangan tersebut (Danandjaya: 1986).Atau bisa juga penyebab kultural dan struktural di atas terjadi secara simultan menyebabkan munculnya penyakit sosial di daerah tertentu, seperti di Jakarta atau daerah-daerah di pinggiran Jakarta (Tangerang, Depok, Ciputat, Bekasi).

Saat ini Jakarta telah menjadi kota raksasa (mega city) yang telah menyatu dengan kotakota di sekelilingnya, menjadi mega urban (Fox, Richard G: 1987)

Munculnya kota raksasa ini dimulai sejak tahun 1973, dengan dikeluarkannya konsep Jabodetabek (Jakarta, Bogor, Depok, Tangerang, Bekasi) untuk mengantisipasi perkembangan kota Jakarta yang semakin luas dan semakin mempengaruhi kota-kota kabupaten di sekitarnya. Konsep Jabodetabek sebenarnya adalah "Dekonsentrasi Panologis" yang diupayakan untuk mendekonsentrasikan kota, ke daerah dan kegiatan-kegiatan baru maupun sebagian yang sudah ada di sekitar Jakarta agar urbanisasi ke Jakarta dapat dikurangi atau dipindahkan ke wilayah sekitarnya.

Konsep Jabodetabek tersebut ternyata memang tepat dengan perkiraan pertambahan penduduk yang mungkin akan terjadi di Jakarta. Di Jakarta pada tahun 1980 penduduknya baru mencapai 6.503,4 juta jiwa dan pada tahun 2019 meningkat menjadi 10,6 juta jiwa (Biro Pusat Statistik, 2019).

Umumnya yang menjadi penyebab utama tingginya tingkat pertumbuhan penduduk di kota adalah faktor urbanisasi, sebagaimana juga terjadi di Jakarta kecenderungan semakin tingginya urbanisasi di Jakarta dari waktu ke waktu semakin tidak terkendali sehingga pada saat tertentu dapat melampaui daya tampung kota, sehingga konsep perluasan wilayah seperti konsep Jabodetabek menjadi pilihan untuk mengurangi munculnya masalah diperkotaan yang lebih kompleks di kemudian hari.

Konsep "Dekonsentrasi Panologis" untuk mengalihkan pertumbuhan penduduk pusat kota ke pusat-pusat kegiatan baru di wilayah pinggiran Jakarta juga didukung dengan dibukanya lapangan pekerjaan, jaringan lalu lintas regional, kompleks-kompleks pemukiman dan tempat-tempat rekreasi, sebagaimana tampak di sekitar wilayah Depok, Bogor, Tangerang dan Bekasi (Munandar:1997).

Tampaknya konsep "Dekonsentrasi Planologis" di atas cukup ampuh, terbukti dengan munculnya pertumbuhan yang lebih tinggi di daerah pinggiran di bandingkan dengan Jakarta. Kalau di Jakarta terjadi tingkat pertumbuhan penduduk sebesar 90 persen antara tahun 1980 - 2019, di daerah pinggiran 
Jakarta ternyata meningkat sebesar 240 persen (Lembaga Demografi FE UI).

Dampak perkembangan pertumbuhan penduduk yang sangat besar pesat di daerah pinggiran kota tersebut dapat di lihat secara langsung dengan perkembangan yang terjadi di daerah Depok, Bogor, Tangerang, Bekasi. Pada saat ini tumbuh kompleks-kompleks pemukiman, pembangunan industri, tempat rekreasi serta berbagai fasilitas umum dan sosial lainnya. Perkembangan yang terjadi di atas juga secara langsung telah menyebabkan harga tanah di kawasan tersebut meningkat pesat. Banyak tanah yang semula kosong"disulap" menjadi pusat-pusat keramaian (Kompas, 4 Maret, 1994). Akibatnya maka areal pertanian, perkebunan yang ada di daerah tersebut berangsur-angsur berubah fungsi menjadi daerah pemukiman dan industri.

Pertumbuhan penduduk yang sangat pesat tersebut yang diikuti oleh perkembangan kota yang sangat pesat juga menyebabkan terjadinya perubahan yang sangat drastis dalam kehidupan masyarakat di daerah pinggiran. Akibat yang terjadi di atas tentu ada yang bersifat positif, seperti meningkatnya sarana pendidikan, terbukanya lapangan pekerjaan dan sebagainya. Tetapi juga ada dampak negatifnya yang menyebabkan terjadinya patologi sosial (penyakit sosial), seperti stress, meningkatnya kriminalitas, pengangguran, kenakalan remaja serta prostitusi pada masyarakat pinggiran tersebut. Dampak negatif tersebut juga terjadi pada remaja di daerah kecamatan Ciputat- Tangerang, yang berada di Selatan Jakarta.

Dampak negatif pada remaja dari perkembangan kota di daerah CiputatTangerang itulah yang akan diungkapkan dalam penelitian ini dengan metode kualitatif. Diharapkan dapat dilanjuti dengan penelitian selanjutnya untuk lebih mendalami persoalan di atas.

\section{Metode}

Penelitian ini menggunakan metode penelitian kualititatif dengan menggunakan pedoman wawancara, terhadap para informan, dan pengamatan. Pertanyaan terstruktur atau sistematis menggunakan kuesioner atau angket, terhadap responden juga digunakan untuk melengkapi data yang diperoleh peneliti.

\section{Hasil dan Pembahasan}

Daerah pinggiran kota, seperti Ciputat, sebagai suatu lingkungan ekologis, terdiri dari tiga aspek yang saling melengkapi dan merupakan satu kesatuan, yaitu lingkungan alam (natural environment) dan lingkungan ekonomi (economic environment) lingkungan budaya (cultural environment). Lingkungan alam merupakan sistem pendukung bagi kehidupan manusia (life support system), berupa penyediaan bahan makanan, udara air dan sumber-sumber alam lainnya. Lingkungan ekonomi meliputi segala macam aktivitas melalui sumber-sumber alam dan sumber daya manusia digunakan untuk memenuhi kebutuhan manusia. Lingkungan cultural meliputi sub-sistem sosial dan politik, yang terdiri atas aktivitas yang berupaya mendorong manusia ke arah yang lebih baik. Yang tercakup dalam lingkungan cultural adalah interaksi antar individu dan kelompok, dan interaksi antara subsistem lingkungan cultural dengan lingkungan ekonomi dan lingkungan alam. (Robert: 1981).

Hal itu berarti jika terjadi perubahan dalam satu aspek akan sangat berpengaruh kepada aspek lainnya. Kaitannya dengan perkembangan fisik kota tentu akan berpengaruh terhadap perkembangan ekonomi maupun sosial budaya di daerah tersebut. Perubahan di atas tidak hanya merubah struktur fisik demografi, ekonomi dan sosial budaya masyarakat 
bersangkutan, desa yang tradisional menjadi karakteristik kehidupan kota yang modern.

Perubahan menjadi karakteristik masyarakat kota di daerah pinggiran dimungkinkan karena munculnya berbagai struktur sosial yang menimbulkan bermacammacam gaya hidup. Di kota juga muncul dorongan untuk membentuk suatu kepribadian sosial dan mengadakan perubahan, karena kota merupakan sarana untuk perubahan sosial (Nas : 1984). Bahkan kota juga dapat dikatakan sebagai bentuk dari perkembangan manusia (Raharjo: 1983). Gillin,Philip : 1984).

Secara psikologis perkembangan kota dapat menyebabkan peningkatan rangsangan syaraf. Dalam kehidupan kota orang bisa mendapat macam-macam kesan yang tak terduga, dan orang harus segera bereaksi dengan patologi sosial (problema sosial). Problema sosial secara sederhana diterjemahkan sebagai suatu ketidak sesuaian antara unsur-unsur dalam kebudayaan atau masyarakat, yang membahayakan kehidupan kelompok masyarakat, atau menghambat terpenuhinya keinginan-keinginan pokok dari warga-warga kelompok sosial tersebut, sehingga menyebabkan rusaknya ikatan sosial (Gilian and Gillin, 1984).

Dalam keadaan normal terdapat integrasi serta keadaan yang sesuai pada hubungan antara unsur-unsur kebudayaan atau masyarakat. Ada suatu persesuaian sosial, dimana semua lembagalembaga secara harmonis terintegrasi. Orangperorangan tidak merasa dirinya tertekan untuk menyesuaikan diri dengan lembaga tersebut. Ada persesuaian sosial antara rumah tangga, moral, politik, pendidikan, agama, kebiasaan dan ekonomi (Cultural Sociology, dalam Soekanto: 1982).

Apabila antara unsur-unsur tersebut terjadi bentrokan, maka hubungan sosial akan terganggu sehingga mungkin terjadi kegoyahan dalam kehidupan kelompok. Problema-problema sosial timbul, karena tidak adanya integrasi yang harmonis antara lembaga-lembaga kemasyarakatan. Orang-perorangan mengalami kesulitan-kesulitan dalam menyesuaikan diri dengan macam-macam hubungan sosial.

Patologi atau problema sosial juga bisa timbul dari kekurangan-kekurangan dalam diri manusia atau kelompok manusia yang bersumber dari faktor-faktor ekonomi, biologi, psikologi dan kebudayaan. Setiap masyarakat mempunyai norma-norma yang bersangkut paut dengan kesejahteraan, kebendaan, kesehatan phisik, kesehatan mental serta penyesuaian diri orang perorangan atau kelompok manusia. Penyimpangan-penyimpangan terhadap normanorma tersebut merupakan gejala yang abnormal dalam masyarakat di atas, $\mathrm{Hal}$ ini di sebut dengan patologi atau problema sosial.

Beberapa patologi sosial yang berdampak pada remaja antara lain stress, kemiskinan, kriminalitas, pelacuran atau prostitusi, serta kenakalan remaja.

\section{Stress}

Adanya perubahan ekonomi, sosial budaya dan lingkungan dapat menimbulkan stress. Karena perubahan yang terjadi begitu cepat menyebabkan mereka perlu waktu yang lama untuk beradaptasi terhadap lingkungan baru. Kemampuan budaya mereka belum tentu dapat didaya gunakan dengan baik untuk menghadapi lingkungan fisik dan sosial budaya di lingkungan yang terlalu cepat berubah.

Di dalam kehidupan masyarakat kota, adanya kemacetan lalu lintas seperti lalu lintas di kawasan Ciputat, Para remaja ketika ingin berangkat sekolah, seringkali terlambat masuk sekolah karena kemacetan lalu lintas. Serta urbanisasi yang menyebabkan berkembangnya pemukiman kumuh, industrialisasi dan penetapan lahan industri yang berakibat dengan penggusuran maupun berbagai tantangan berat bagi pihak yang tergusur, merupakan sumber- 
sumber terjadinya stress, khususnya yang dikenal dengan istilah stress psikokultural, stress yang terjadi karena faktor-faktor budaya, dan stress psikososial, stress yang terjadi karena faktorfaktor sosial yang berkenaan dengan berbagai masalah interaksi sosial (Swasono, 1991:6).

Seiring dengan berkembangnya kota Ciputat dan banyaknya dibangun kompleks perumahan dan pertokoan. Hal tersebut dapat menimbulkan kerusakan lingkungan yang merupakan salah satu bentuk stressor bagi masyarakat Ciputat, khususnya bagi remaja. Contohnya daerah atau lingkungan untuk resapan air semakin berkurang dan menghilang. Sebelumnya banyak terdapat situ atau danau, seperti situ kuru dan situ gintung, kini danau tersebut telah penuh dengan rumah dan pohonpohon yang rimbun di sekitarnyapun telah hilang. Udara yang tadinya sejuk kini berubah menjadi agak panas dan hal tersebut juga dapat menyebabkan banjir di wilayah sekitarnya, yang tadinya mereka tidak pernah mengalami kebanjiran.

Meningkatnya jumlah penduduk dan banyaknya kompleks perumahan di sekitar kawasan Ciputat, banyaknya motor-motor, mobil-mobil pribadi, mobil-mobil angkot, mobil-mobil bus yang berhenti tanpa aturan, serta kondisi terminal Ciputat yang tidak berfungsi sebagaimana mestinya, karena lokasinya yang di pindah jauh dari pasar tradisional (terbakar pada tahun 1994, kini dibangun Ciputat Mall). Keadaan tersebut membuat daerah Ciputat menjadi kawasan yang sangat macet dan polusi dari asap-asap mobil dan motor yang membuat sesak pernapasan dan menimbulkan suara atau suasana yang bising. Karena para pengemudi sering tidak sabar dan saling mendahului, dengan klakson yang keras dan sering kali dibunyikan. Sehingga remaja di wilayah Ciputat lebih mudah terkena stress di bandingkan dengan remaja di tempat lain yang lingkungannya tidak ramai dan macet.
Salah satu bentuk stress pada masyarakat Ciputat, khususnya remaja yaitu adanya penggusuran yang dilakukan dengan alasan demi penataan kota. Salah satu alasannya adalah karena pemukiman tertentu dengan penduduk yang padat dianggap kurang memenuhi persyaratan bagi kesehatan lingkungan yang baik. Alasan lain yang nampak menonjol dan selalu menjadi sumber pemberitaan media massa adalah meningkatnya kebutuhan lahan bagi pembangunan perekonomian. Maka lokasilokasi pemukiman, baik yang kumuh maupun tidak kumuh, yang menurut penilaian perencanaan pembangunan akan memberikan manfaat ekonomi yang lebih besar, tidak bisa lagi dipertahankan sebagai tempat pemukiman.

Dalam kasus ini, terjadi ketika akan dibangunnya kompleks-kompleks perumahan elit dan mewah di kawasan Ciputat. Banyak penduduk asli yang tergusur dan pindah ke tempat yang lebih jauh, bagi para remaja yang orang tuanya penduduk asli kondisi hal tersebut membuat mereka stress

Kasus penggusuran yang terjadi di atas, mencerminkan apa yang dikatakan Swasono (1991), bahwa nilai-nilai tradisi dan historis sebagai sumber asli hak hukum rakyat, yang kemudian menjadi hak politiknya, sering digeser hak hukum baru oleh birokrasi dalam bentuk baru yang lebih pragmatis, yang seringkali atas pengorbanan yang lemah ... dalam hal ini. “ rakyat dipesisir-pesisir digeser oleh investorinvestor pendatang yang memegang lahan dari instansi resmi. Penggeseran ini meliputi penggeseran pula pekerjaan atau matapencarian mereka. Para investor ini menjadi pendatang baru dengan hak hukum baru..." (Swasono, 1991:50).

Kondisi perekonomian di Indonesia yang mengalami krisis terus menerus, menimbulkan banyak pengangguran. Kondisi tersebut juga berimbas pada masyarakat Ciputat. Menurut wawancara yang dilakukan oleh Kapolsek 
Ciputat. Pengaduan masyarakat karena suami sebagai kepala rumah tangga menganggur tidak bekerja, yang akhirnya berakibat stress, dan sering menjadi mudah marah, gejala-gejala tersebut merugikan dan mengganggu keharmonisan rumah tangga. Sehingga tingkat perceraian meningkat. Kondisi tersebut mempunyai dampak negatif bagi perkembangan remaja.

\section{Kemiskinan}

Terjadinya migrasi disebabkan karena faktor penarik atau pendorong yang menyebabkan para penduduk yang berasal dari daerah atau pedesaan, bermigrasi ke Jakarta untuk mencari nafkah dan berharap agar kehidupannya menjadi lebih baik, tanpa pendidikan serta ketrampilan yang cukup menyebabkan mereka menjadi tersisih dan kalah bersaing dengan mereka yang memiliki kemampuan yang lebih baik.

Kaum urban ini lebih banyak bekerja di sektor-sektor informal seperti tukang semir sepatu, pedagang singkong, pemulung dan sebagainya. Seperti yang terjadi di daerah Ciputat, mereka menempati tanah negara yang merupakan tanah milik Kementrian Agama, yang terletak di desa Pisangan.

Tanah negara tersebut, pada mulanya digunakan untuk tempat pembuangan sampah akhir bagi para penduduk kompleks UIN (yang juga tergusur untuk perkembangan kampus), tetapi lambat laun tanah tersebut kini banyak dibangun pemukiman kumuh, dimana sebagian besar dari mereka menjadi pemulung, dan bekerja di sektor informal.

Para penduduk yang menempati daeerah tersebut sebagai besar berasal dari Madura, Bima, beberapa dari daerah Sukabumi. Terdapat sekitar 100 rumah yang mendiami tanah negara tersebut dan hingga saat ini, mereka mulai membangun rumah secara permanen.
Oscar Lewis (1978:13) berpendapat bahwa masyarakat kota yang miskin tinggal di dalam suatu "kebudayaan kemiskinan" (culture of poverty) yang timbul secara otomatis dari dorongan ekonomi dan politik yang mereka alami, yang kemudian membentuk organisasiorganisasi kekeluargaan, pola-pola kepercayaan dan tingkah laku kerja yang berlawanan dengan nilai-nilai masyarakat yang lebih luas.

Terdapat kemiskinan di masyarakat, menyebabkan terbentuknya pemukiman kumuh di tanah negara milik Kementrian Agama tersebut, banyak menimbulkan masalah, tidak saja masalah dari segi fisik, melainkan juga dari segi sosial -budaya, dan psikologi para penghuninya. Bangunan dan lingkungan rumah yang sangat berdesakan, tidak memberikan makna budaya dan sistem simboliknya, tidak dapat berperan sebagai wadah kegiatan agama dan ritual, tidak pula dapat memberikan rasa aman secara psikologis dan menjadi wadah pembinaan mental untuk menciptakan kehangatan dalam kehidupan keluarga. (Swasono: 1989,1991).

Pemukiman kumuh hanya mampu memberikan tempat istirahat fiik bagi penghuninya, kesempatan mencari rezeki, sebagai kuli, pemulung, atau pekerjaan-pekerjaan yang layak bagi kemanusiaan. Secara keseluruhan pemukiman kumuh hanya memberikan penurunan terhadap martabat manusia dari sebagian besar penduduk yang terurbanisasi.Serta memberikan dampak yang buruk bagi perkembangan remaja.

\section{Kriminalitas}

Perkembangan kota, khususnya kota Ciputat yang semakin pesat juga menimbulkan peningkatan kriminalitas.Terdapat beberapa orang yang mengambil jalan pintas dengan melakukan berbagai kejahatan agar tetap dapat survive. Adanya kecemburuan sosial dengan para 
pendatang dengan tingkat ekonomi yang lebih tinggi, sehingga menimbulkan kesenjangankesenjangan, yang kaya semakin kaya dan yang miskin semakin tertindas (Gressey R. Donald :1981).

Kejahatan-kejahatan yang dilakukan, seperti menjadi copet di pasar Ciputat atau pusat -pusat perbelanjaan, atau menjadi pencuri dengan mengambil barang-barang berharga. Banyaknya pemulung masuk ke komplekskompleks perumahan, dengan dalih mencari sampah, terkadang mereka juga mencuri-curi kesempatan untuk mengambil sepatu, atau pakaian-pakaian yang di jemur di teras atau belakang rumah. Kasus ini sudah beberapa kali terjadi, dan tertangkap basah oleh pemiliknya, sehingga pihak kemanan kompleks perumahan tetap disiagakan.

Demikian juga kasus, perampokan banyak terjadi, menurut data yang diperoleh dari Polsek Ciputat, angka kejahatan baik pencurian atau perampokan dengan cara membunuh korbannya, meningkat 10\% dibandingkan 5 tahun sebelumnya. Kondisi tersebut tiap tahun mengalami peningkatan.

Preman-preman dan anak punk jalanan juga banyak terdapat di kawasan Ciputat, mereka menguasai tempat-tempat tertentu, dan mempunyai gank/kelompok. Keberadaan para anak punk jalanan ini sangat meresahkan masyarakat, karena mereka sering meminta paksa para korbannya, dengan mengamen dan memaksa meminta imbalan uang, kepada pada para pelajar, serta supir-supir angkutan umum yang sering menjadi mangsa mereka. Dengan berdalih sebagai calo (mencari penumpang) di daerah kekuasaan mereka, dan merekapun meminta imbalan uang. Walaupun diberikan dengan sangat terpaksa oleh para supir. Para remaja yang berangkat sekolah pun sering di ganggu oleh preman atau anak anak punk yang tersebar di jalan sekitar Ciputat.
Kriminalitas berupa peredaran narkoba dan obat psikotropika juga terdapat di wilayah Ciputat. Menurut Kapolsek Ciputat, daerah rawan peredarannya yaitu daerah Rempoa (Mabad) dan dekat Bintaro Sektor II, jalan WR Supratman. Penahanan terhadap para pemakai sering dilakukan di polsek Ciputat. Beberapa remaja di wilayah Ciputat, juga terkena kasus narkoba.

\section{Pelacuran}

Tempat-tempat pelacuran, terbuka/terselubung juga terdapat di daerah Ciputat dan sekitarnya. Tempat tersebut biasanya berada di daerah sepanjang arah Parung (Bogor) hingga Ciputat, letaknya bisa berada di rumah-rumah makan, panti pijat, losmenlosmen atau warung remang-remang, bahkan juga Apartemen apartemen yang ada disekitar Ciputat.

Selain pelacuran yang dilakukan oleh para WTS (Wanita Tuna Susila), pelacuran juga dilakukan oleh para waria. Mereka biasanya secara terbuka menjajakan dirinya di sepanjang jalan sekitar Lebak Bulus- Pasar Jumat hingga Pasar Ciputat. Dengan rias wajah yang sangat menyolok serta pakaian yang sangat minim, memanggil-manggil laki-laki iseng untuk kencan bersama. Para waria dan lelaki iseng yang menggunakan mereka, mempunyai masalah penyimpangan seksual (deviant) yaitu prilaku homoseksual, karena mereka melakukan dengan sesama jenis kelamin.

Penyakit AID'S atau penyakit kelamin lainnya, dapat tersebar dengan adanya pelacuranpelacuran tersebut di atas. Penyakit menular seksual juga dialami oleh beberapa remaja di wilayah Ciputat. 


\section{Kenakalan Remaja}

Salah satu tempat hiburan (game on line) di wilayah Ciputat, berdasarkan pengamatan banyak para remaja menghabiskan waktunya di tempat tersebut. Ada beberapa remaja yang bolos sekolah untuk bermain game on line.

Pada jam-jam pulang sekolah, baik anak-anak Sekolah Menengah Pertama (SMP) atau SMA (Sekolah Menengah Atas) banyak memadati tempat-tempat hiburan, bahkan merekapun ketika jam sekolah juga berada di tempat tersebut. Ajakan teman bermain (peer group) seperti untuk merokok, meminum minuman keras, atau mencoba obat-obat terlarang, juga dilakukan mereka di suatu tempat tertentu dengan cara bersembunyi-sembunyi.

Para pelajar yang bermukim di kawasan Ciputat, mereka juga banyak yang bersekolah di lingkungan Ciputat. Tawuran (perkelahian sesama pelajar) dapat terjadi. Walaupun penyebabnya merupakan masalah-masalah yang sangat sederhana/sepele, seperti pacarnya diganggu oleh pelajar dari sekolah lain, saling berebut bis angkutan, dan sebagainya.

Berdasarkan pengamatan. Kasus perkelahian remaja terjadi pada para pelajar SMEA (Sekolah Menengah Ekonomi Atas) Yayasan Miftahul Jannah dengan STM Triguna yang letak sekolahnya berdekatan, di sekitar jalan Ir. H. Juanda Ciputat. Para pelajar ini, ketika bergabung bersama kelompoknya, menjadi sangat kasar, brutal serta sulit dikendalikan karena histeria massa.

Penyebab kenakalan remaja, selain karena faktor interen, yaitu dorongan-dorongan aku, dan dorongan seks. Juga karena faktor ekstern, berupa lingkungan tempat tinggal, teman bermain, lingkungan keluarga (orang tua yang terlalu sibuk dengan urusannya sendiri, sehingga para remaja tersebut tidak mendapat perhatian, dan lebih senang melakukan kegiatan yang negatif bersama kelompok bermainnya/peer group).

\section{Simpulan}

Perkembangan daerah kawasan CiputatKabupaten Tangerang Selatan, tidak bisa dihindari karena ibu kota Jakarta, bergerak menjadi kota raksasa (mega city), karena batas antara kota-kota Bodetabek (Bogor, Depok, Tangerang, Bekasi) sudah menjadi kabur.

Perkembangan wilayah Ciputat yang semakin pesat selain mempunyai dampak positif berupa peningkatan sarana fisik, seperti jalan aspal, listrik, telepon, transportasi, dan fasilitas lainnya juga mempunyai dampak negatif.

Berkembangnya suatu kota tidak lepas dari masalah patologi sosial (penyakit sosial) yang berdampak pada remaja seperti stress, meningkatnya kriminalitas, pengangguran, kenakalan remaja serta prostitusi.

Saran penulis adalah Perlu dikampanyekan atau diprogramkam oleh pemerintah melalui media massa, baik TV maupun radio dan sebagainya, bahwa kehidupan dikota lebih sulit persaingannya dibanding dengan di desa, dan jika ingin tinggal di kota, mereka harus memiliki kemampuan ketrampilan dan pendidikan yang cukup, sehingga mereka dapat survive dengan baik dan masalah kemiskinan di perkotaan dapat ditekan. Tingkat kriminalitas di Ciputat, perlu di waspadai, keamanan di lingkungan perumahan-perumahan maupun oleh Polsek Ciputat perlu ditingkatkan. Preman preman dan anak anak punk jalanan yang meresahkan masyarakat, berdampak buruk bagi remaja agar segera ditangani oleh kepolisian setempat. Agar kenakalan remaja, tidak semakin meningkat, diharapkan penyebab dari faktor-faktor ekstern perlu diperhatikan. Diharapkan pengelolapengelola hiburan agar tidak hanya mencari keuntungan. Seperti rental-rental game station atau billiard, dianjurkan untuk tidak membolehkan siswa yang berseragam untuk 
bermain di sana. Orang tua agar mengawasi anaknya dalam penggunaan internet untuk hal yang positif bukan negatif, seperti mengeksploitasi seksualitas dan sadisme, untuk menarik penonton. Prostitusi diminimalisir, dengan memberikan lapangan pekerjaan yang memadai bagi para WTS

\section{Daftar Pustaka}

Biro Pusat Statistik, 2019

Danandjaya, James. Antropologi Pikologi. Jakarta: Rajawali Perss. 1986.

Fox, Richard G., People in Cities: The Urban Environment and its effect. Sidney: Cambridge University Press. 1987

Gillin, John Lewis-Gillin, Jhon Philip. Cultural Sociology. (Third Printing). New York: The Mac Millan Company, 1984.

Gressey R. Donald."Crime” dalam Contemporary Social Problems an Introduction to The Sociology of deviant Behavior and Social Disorganization. New York:1981.

Kompas, 4 Maret 1994.

Merton, K. Robert and Nisbet A. Robert. Contemporary Social Problems an Introduction to The Sociology of deviant Behavior and Social Disorganization. New York:1981.
Munandar, Aris. "Urbanisasi dan Perubahan Sosial Ekonomi Masyarakat Pinggiran Kota Jakarta”. Dalam Jurnal Kampus Tercinta. No.5 Tahun II. Agustus 1997.

P.J.M. Nas, Kota di Dunia Ke tiga: Pengantar Sosilogi Kota. Terj. Sukanti S. Bandung: Bhatara Karya Aksara. 1984.

Poskota, 5 Juni 2001.

Raharjo. Perkembangan Kota dan Permasalahannya. Jakarta: Bina Aksara, 1983.

Soekanto, Soerjono. "Pendidikan dan Usaha Preventif dan Refresif Untuk Membatasi Pelacuran Khususnya di daerah Jakarta Raya”. (Makalah: Sumbangan Pemikiran Kepada Pemda DKI). 1988.

Suara Pembaruan, 14 Mei 2000.

Swasono, Meutia Farida. "Efek Pembangunan Fisik Terhadap Kesehatan Masyarakat: Urbanisasi, Penggusuran dan Stress" dalam makalah pada temuan tahunan IV Jen di Yogyakarta: 2-7, Desember 1991.

Swasono, Meutia Farida. "Gangguan Jiwa Dalam Pandangan Budaya Masyarakat dan Faktor Sosial Budaya Sebagai Pendorong Gangguan Jiwa: Suatu Tinjauan Antropologi Budaya”. Makalah. Jakarta, 10 Desember 1989. 